\title{
Ministry of Health Clinical Practice Guidelines: Anxiety Disorders
}

\author{
Leslie Lim, Hong Ngee Chan, Peng Hoe Chew, Sze Ming Chua, Carolyn Ho, Seow Khee Daniel Kwek, Tih Shih Lee, \\ Patricia Loh, Alvin Lum, Yong Hui Colin Tan, Yi Min Wan, Matthew Woo, Hwa Ling Yap
}

ABSTRACT The Ministry of Health $(\mathrm{MOH})$ has developed the clinical practice guidelines on Anxiety Disorders to provide doctors and patients in Singapore with evidence-based treatment for anxiety disorders. This article reproduces the introduction and executive summary (with recommendations from the guidelines) from the MOH clinical practice guidelines on anxiety disorders, for the information of SMJ readers. Chapters and page numbers mentioned in the reproduced extract refer to the full text of the guidelines, which are available from the Ministry of Health website: http://www.moh. gov.sg/content/moh_web/healthprofessionalsportal/doctors/guidelines/cpg_medical.html. The recommendations should be used with reference to the full text of the guidelines. Following this article are multiple choice questions based on the full text of the guidelines.

\subsection{Background information}

Anxiety disorders are known to be one of the most prevalent of psychiatric conditions, yet they often remain under-diagnosed and under-treated. Their chronic, disabling symptoms cause considerable burden not only to sufferers but also to their families, and contribute to poorer quality of life and considerable economic burden on society.

In many instances, there is a delay in seeking treatment and in some cases such delay may stretch up to nearly ten years. This may result from ignorance of the condition, fear of taking medications, and the stigma of receiving a psychiatric diagnosis, and or having to accept psychiatric treatment.

The anxiety disorders include panic disorder with or without agoraphobia, social anxiety disorder, specific phobia, obsessivecompulsive disorder, generalised anxiety disorder, acute stress disorder and post-traumatic stress disorder. In the clinical evaluation of anxiety disorders, it is important to ascertain the type of anxiety disorder present. This would allow treatment to be targeted at the specific type of disorder.

These guidelines are developed to provide practical, evidence-based recommendations to primary care physicians and specialists in psychiatry for the diagnosis and management of the anxiety disorders.

The first edition of the guidelines was published in 2003. In this edition, we present data from newer research as well as older data not previously reported in the earlier guidelines.

For example, we examine the efficacy of combining medications with psychological therapy over medications alone, or psychological therapy alone. In view of the majority of anxiety sufferers being female we have made recommendations for pharmacotherapy during pregnancy and breastfeeding. As these guidelines are intended for use in the Singapore context, we have omitted treatments that are currently not available in Singapore.

\subsection{Aim}

These guidelines are developed to facilitate the diagnosis and assessment of the anxiety disorders, and to ensure that their management is appropriate and effective.

\subsection{Scope}

These guidelines will cover the management of anxiety disorders in adults and address the issues of medication use during pregnancy and breastfeeding.

\subsection{Target group}

The content of the guidelines will be useful for all doctors treating patients with anxiety disorders. Efforts have been made to ensure that the guidelines are particularly useful for primary care physicians and specialists in psychiatry, including all those involved in the assessment and management of patients with anxiety disorders in the community. The doctor treating the patient is ultimately responsible for clinical decisions made after reviewing the individual patient's history, clinical presentation and treatment options available.

\subsection{Development of guidelines}

These guidelines have been produced by a committee of psychiatrists, a clinical psychologist, pharmacist, patient representative, and family practitioners appointed by the Ministry of Health. They were developed by revising the existing guidelines, reviewing relevant literature, including overseas clinical practice guidelines, and by expert clinical consensus of professionals with experience in treating patients in the local setting. 
The following principles underlie the development of these guidelines:

- Treatment recommendations are supported by scientific evidence whenever possible (randomised controlled clinical trials represent the highest level of evidence) and expert clinical consensus is used when such data are lacking.

- Treatment should maximise therapeutic benefits and minimise side effects.

\subsection{What's new in the revised guidelines}

This edition of the guidelines contains updated recommendations based on latest evidence, as well as detailed discussions and recommendations on the management of anxiety disorders in adult populations.

The following represent changes to the revised guidelines

- An extensive review of the literature, including new evidence. This involved the re-writing and extensive revision of the chapters.

- Length of treatment, which provides answers to a pertinent question.

- Use of medications during pregnancy and breastfeeding. Given that females are more likely to be at risk of being diagnosed with anxiety disorders, this is an important subject.

We are aware that the Diagnostic and Statistical Manual of Mental Disorders-5 (DSM-5) was released in 2013. In DSM-5, post-traumatic stress disorder and obsessive-compulsive disorder

\section{Clinical Evaluation and Overview}

have been removed and classified separately from the rest of the anxiety disorders. If we were to adhere strictly to DSM-5, this would entail omitting discussion on post-traumatic stress disorder and obsessive-compulsive disorder. As it is our aim to provide an update on the 2003 guidelines, post-traumatic stress disorder and obsessive-compulsive disorder have been included in this edition of the guidelines.

In addition, anxiety conditions in children are included in DSM-5. Since the present guidelines are meant to address only adult anxiety disorders, guidelines on children's anxiety conditions are not included here.

Hence, for purposes of these guidelines, we will continue to use classifications based on the International Classification of Diseases-10 (ICD-10) and DSM-IV-TR criteria.

\subsection{Review of guidelines}

Evidence-based clinical practice guidelines are only as current as the evidence that supports them. Users must keep in mind that new evidence could supersede recommendations in these guidelines. The workgroup advises that these guidelines be scheduled for review five years after publication, or when new evidence appears that requires substantive changes to the present recommendations.

\section{EXECUTIVE SUMMARY OF RECOMMENDATIONS}

Details of the recommendations listed can be found in the main text as the pages indicated. Key recommendations are shaded in grey.

\begin{tabular}{|c|c|c|c|}
\hline No. & Recommendation & $\begin{array}{l}\text { Grade, } \\
\text { Level of evidence }\end{array}$ & $\begin{array}{l}\text { CPG } \\
\text { page no. }\end{array}$ \\
\hline 1 & $\begin{array}{l}\text { A diagnosis of anxiety disorder should be considered only after appropriate clinical } \\
\text { evaluation and investigation to rule out general medical conditions have been done. } \\
\text { Figure } 1 \text { summarises how the various anxiety disorders are diagnosed. }\end{array}$ & GPP & 16 \\
\hline 2 & $\begin{array}{l}\text { The initial management of anxiety disorders should ideally be instituted at the primary } \\
\text { care level. The recommended framework for the management of anxiety disorders in } \\
\text { primary care is described in Figure } 2 \text {. }\end{array}$ & GPP & 22 \\
\hline 3 & $\begin{array}{l}\text { The following may be instituted in primary care immediately after diagnosis: } \\
\text { - Educating patient on nature and origin of anxiety symptoms and providing } \\
\text { appropriate reassurance, e.g., not having a 'heart attack' or 'going crazy' } \\
\text { - Suggestion of lifestyle changes as appropriate, i.e., stress reduction strategies, } \\
\text { reducing alcohol and caffeine intake, avoiding nicotine and drug use, regular exercise } \\
\text { - Supportive counselling } \\
\text { - Symptomatic relief with medication prescribed on a short-term basis } \\
\text { - Evaluation and mobilisation of family and social resources } \\
\text { - Monitoring and addressing early signs of relapse }\end{array}$ & $\begin{array}{l}\text { Grade D, } \\
\text { Level } 4\end{array}$ & 22 \\
\hline 4 & $\begin{array}{l}\text { Psychiatric evaluation and treatment is appropriate when there is serious risk of suicide, } \\
\text { there are psychotic symptoms, co-occurring drug/alcohol problems exist, symptoms are } \\
\text { severe/complex or if symptoms fail to improve on initial treatment and follow-up. }\end{array}$ & GPP & 27 \\
\hline 5 & $\begin{array}{l}\text { Consider transferring patients with anxiety disorders from psychiatric to primary care } \\
\text { for long-term management if they have the following characteristics: } \\
\text { - Aged } 18 \text { or older } \\
\text { - Stabilised for the past } 3 \text { months } \\
\text { - No psychiatric hospitalisation in the past } 6 \text { months } \\
\text { - No history of forensic or substance abuse } \\
\text { - No disruptive personality disorders } \\
\text { - Non suicidal } \\
\text { - No history of aggressive behaviour } \\
\text { - Not currently receiving clozapine, lithium, valproate, hypnotics (including } \\
\text { benzodiazepines, zopiclone, zolpidem) or formal psychotherapy treatment }\end{array}$ & GPP & 27 \\
\hline
\end{tabular}




\begin{tabular}{|llll|}
\hline No. & Recommendation & $\begin{array}{c}\text { Grade, } \\
\text { Level of evidence }\end{array}$ & \multicolumn{1}{c|}{$\begin{array}{c}\text { CPG } \\
\text { page no. }\end{array}$} \\
\hline 6 & $\begin{array}{l}\text { All patients should receive education about their disorder, including aetiology, treatment } \\
\text { choices and prognosis. }\end{array}$ & GPP \\
\hline 7 & $\begin{array}{l}\text { As local patients may show higher propensity for initial side effects of } \\
\text { antidepressants (e.g. paradoxical excitation), starting doses for local patients should be } \\
\text { lower than those suggested by overseas guidelines. }\end{array}$ & GPP & 30 \\
\hline 8 & $\begin{array}{l}\text { The Clinical Global Impression scales (both severity and improvement sub-scales) may } \\
\text { be used to measure illness severity and treatment progress during consultations for } \\
\text { anxiety disorders. }\end{array}$ & Grade B, \\
\hline
\end{tabular}

\section{Management of Panic Disorder}

\begin{tabular}{|lllc|} 
No. & Recommendation & $\begin{array}{l}\text { Grade, } \\
\text { Level of evidence }\end{array}$ & $\begin{array}{l}\text { CPG } \\
\text { page no. }\end{array}$ \\
\hline 9 & $\begin{array}{l}\text { Either selective serotonin reuptake inhibitors (SSRIs) or venlafaxine should be used as } \\
\text { first-line agents for the pharmacological treatment of panic disorder. }\end{array}$ & $\begin{array}{l}\text { Grade A, } \\
\text { Level 1+ }\end{array}$ \\
\hline 10 & $\begin{array}{l}\text { Imipramine and clomipramine are effective and may be used as second-line treatment of } \\
\text { panic disorder. }\end{array}$ & $\begin{array}{l}\text { Grade A, } \\
\text { Level 1+ }\end{array}$ \\
\hline 11 & $\begin{array}{l}\text { Benzodiazepines may be added to antidepressants in the short term to produce a more } \\
\text { rapid therapeutic response in the treatment of panic disorder. In view of addictive } \\
\text { potential, benzodiazepines should be tapered and withdrawn by 4 weeks. }\end{array}$ & $\begin{array}{l}\text { Grade A, } \\
\text { Level 1+ }\end{array}$ \\
\hline 12 & $\begin{array}{l}\text { Depending on availability of treatment and patient preference, cognitive behaviour } \\
\text { therapy (CBT) or combination therapy (i.e. CBT and SSRIs or venlafaxine) may be used } \\
\text { for the treatment of panic disorder. }\end{array}$ & $\begin{array}{l}\text { Grade A, } \\
\text { Level 1++ }\end{array}$ \\
\hline
\end{tabular}

\section{Management of Generalised Anxiety Disorder (GAD)}

\begin{tabular}{|c|c|c|c|}
\hline No. & Recommendation & $\begin{array}{l}\text { Grade, } \\
\text { Level of evidence }\end{array}$ & $\begin{array}{l}\text { CPG } \\
\text { page no. }\end{array}$ \\
\hline 13 & $\begin{array}{l}\text { Either SSRIs or venlafaxine should be used as first-line pharmacological treatment for } \\
\text { patients with GAD. }\end{array}$ & $\begin{array}{l}\text { Grade A, } \\
\text { Level } 1++\end{array}$ & 38 \\
\hline 14 & $\begin{array}{l}\text { Imipramine may be considered as a second-line treatment for GAD, in view of the } \\
\text { possibility of poor tolerability and the danger of fatal overdosage. }\end{array}$ & $\begin{array}{l}\text { Grade A, } \\
\text { Level 1+ }\end{array}$ & 38 \\
\hline 15 & $\begin{array}{l}\text { Mirtazapine may be considered as a second-line treatment for GAD due to its anxiolytic } \\
\text { effects. }\end{array}$ & $\begin{array}{l}\text { Grade A, } \\
\text { Level 1+ }\end{array}$ & 38 \\
\hline 16 & Benzodiazepines should not be used for the long-term treatment of GAD. & $\begin{array}{l}\text { Grade B, } \\
\text { Level 1+ }\end{array}$ & 39 \\
\hline 17 & $\begin{array}{l}\text { Pregabalin may be prescribed for patients with GAD as it has anxiolytic effects which } \\
\text { may be more rapid acting. Due caution must be exercised when prescribing to patients } \\
\text { who are at risk of abusing substances. }\end{array}$ & $\begin{array}{l}\text { Grade B, } \\
\text { Level 2++ }\end{array}$ & 39 \\
\hline 18 & $\begin{array}{l}\text { Hydroxyzine may be used as adjunctive treatment together with other anxiolytic agents } \\
\text { for treatment of GAD. }\end{array}$ & $\begin{array}{l}\text { Grade C, } \\
\text { Level 2+ }\end{array}$ & 39 \\
\hline 19 & $\begin{array}{l}\text { Propanolol is not recommended for the long-term treatment of generalised anxiety } \\
\text { disorder. }\end{array}$ & $\begin{array}{l}\text { Grade B, } \\
\text { Level } 1+\end{array}$ & 39 \\
\hline 20 & $\begin{array}{l}\text { Drug treatment for GAD needs to be continued for at least } 32 \text { weeks as high relapse } \\
\text { rates were reported after discontinuing medications. }\end{array}$ & $\begin{array}{l}\text { Grade A, } \\
\text { Level 1+ }\end{array}$ & 40 \\
\hline 21 & CBT may be used as first-line psychotherapy treatment for GAD. & $\begin{array}{l}\text { Grade A, } \\
\text { Level } 1++\end{array}$ & 40 \\
\hline 22 & $\begin{array}{l}\text { A specialist's opinion should be sought for patients with complex GAD and/or with } \\
\text { marked functional impairment, or at high risk of self-harm. }\end{array}$ & GPP & 40 \\
\hline
\end{tabular}

\section{Management of Specific Phobia}

\begin{tabular}{|c|c|c|c|}
\hline No. & Recommendation & $\begin{array}{l}\text { Grade, } \\
\text { Level of evidence }\end{array}$ & $\begin{array}{l}\text { CPG } \\
\text { page no. }\end{array}$ \\
\hline 23 & CBT should be used as first-line treatment of specific phobia. & $\begin{array}{l}\text { Grade A, } \\
\text { Level } 1++\end{array}$ & 41 \\
\hline 24 & $\begin{array}{l}\text { Benzodiazepines may be used on a short-term basis for temporary anxiety relief in } \\
\text { specific phobia, pending resolution of symptoms with other forms of treatment. }\end{array}$ & $\begin{array}{l}\text { Grade B, } \\
\text { Level } 1+\end{array}$ & 42 \\
\hline
\end{tabular}


Management of Social Anxiety Disorder (SAD)

\begin{tabular}{|c|c|c|c|}
\hline No. & Recommendation & $\begin{array}{l}\text { Grade, } \\
\text { Level of evidence }\end{array}$ & $\begin{array}{l}\text { CPG } \\
\text { page no. }\end{array}$ \\
\hline 25 & $\begin{array}{l}\text { Either pharmacotherapy or psychotherapy alone may be used as first-line treatment for } \\
\text { SAD, depending on patient preferences, values and economic considerations. }\end{array}$ & $\begin{array}{l}\text { Grade A, } \\
\text { Level } 1++\end{array}$ & 43 \\
\hline 26 & Either SSRIs or venlafaxine should be used as first-line pharmacotherapy for SAD. & $\begin{array}{l}\text { Grade A, } \\
\text { Level } 1+\end{array}$ & 44 \\
\hline 27 & $\begin{array}{l}\text { Moclobemide may be used for the treatment of SAD if treatment with SSRIs or } \\
\text { venlafaxine has not been effective. }\end{array}$ & $\begin{array}{l}\text { Grade A, } \\
\text { Level } 1+\end{array}$ & 44 \\
\hline 28 & $\begin{array}{l}\text { Benzodiazepines may be used on a short-term basis for temporary anxiety relief pending } \\
\text { resolution of phobic symptoms with other forms of treatment. }\end{array}$ & $\begin{array}{l}\text { Grade A, } \\
\text { Level } 1+\end{array}$ & 44 \\
\hline 29 & $\begin{array}{l}\text { Beta-blockers (e.g. atenolol, propranolol) are not recommended for the treatment of } \\
\text { SAD, as they have been found ineffective. However, they may be used for the treatment } \\
\text { of performance anxiety (e.g. playing an instrument, giving a speech). }\end{array}$ & $\begin{array}{l}\text { Grade B, } \\
\text { Level } 2++\end{array}$ & 45 \\
\hline 30 & CBT should be used as first-line psychotherapy treatment of SAD. & $\begin{array}{l}\text { Grade A, } \\
\text { Level } 1+\end{array}$ & 45 \\
\hline 31 & $\begin{array}{l}\text { Pharmacotherapy with SSRIs, venlafaxine, or moclobemide in SAD should be continued } \\
\text { for at least } 12 \text { months to prevent relapse. }\end{array}$ & $\begin{array}{l}\text { Grade B, } \\
\text { Level } 2++\end{array}$ & 45 \\
\hline
\end{tabular}

Management of Obsessive-Compulsive Disorder (OCD)

\begin{tabular}{|c|c|c|c|}
\hline No. & Recommendation & $\begin{array}{l}\text { Grade, } \\
\text { Level of evidence }\end{array}$ & $\begin{array}{l}\text { CPG } \\
\text { page no. }\end{array}$ \\
\hline 32 & $\begin{array}{l}\text { Either pharmacotherapy or psychotherapy alone may be chosen as first-line treatment } \\
\text { for OCD, depending on patient preferences, values and economic considerations. }\end{array}$ & $\begin{array}{l}\text { Grade A, } \\
\text { Level } 1^{++}\end{array}$ & 46 \\
\hline 33 & $\begin{array}{l}\text { The first-line pharmacological treatment for OCD should be a 10-12 week trial with an } \\
\text { SSRI at adequate doses. }\end{array}$ & $\begin{array}{l}\text { Grade A, } \\
\text { Level } 1++\end{array}$ & 47 \\
\hline 34 & $\begin{array}{l}\text { Clomipramine may be used as a treatment for OCD after an adequate trial of SSRI } \\
\text { treatment has failed. }\end{array}$ & $\begin{array}{l}\text { Grade A, } \\
\text { Level } 1^{++}\end{array}$ & 47 \\
\hline 35 & $\begin{array}{l}\text { An adequate treatment trial in OCD should last for at least } 12 \text { weeks. If the patient } \\
\text { does not respond to treatment in adequate dosages, the medication may be changed or } \\
\text { specialist opinion sought. }\end{array}$ & $\begin{array}{l}\text { Grade D, } \\
\text { Level } 4\end{array}$ & 48 \\
\hline 36 & $\begin{array}{l}\text { Venlafaxine may be considered in patients who have not responded to SSRIs and } \\
\text { clomipramine. Monitor blood pressure during treatment as venlafaxine at high doses } \\
\text { can raise blood pressure. }\end{array}$ & $\begin{array}{l}\text { Grade A, } \\
\text { Level 1+ }\end{array}$ & 48 \\
\hline 37 & $\begin{array}{l}\text { CBT may be used as first-line treatment for OCD if patients prefer psychological } \\
\text { treatment over pharmacotherapy. }\end{array}$ & $\begin{array}{l}\text { Grade A, } \\
\text { Level 1+ }\end{array}$ & 49 \\
\hline 38 & $\begin{array}{l}\text { CBT augmentation of serotonergic antidepressants (e.g. SSRIs, clomipramine) in the } \\
\text { treatment of OCD may be considered for those who are treatment-resistant or partially } \\
\text { responsive to medications. }\end{array}$ & $\begin{array}{l}\text { Grade B, } \\
\text { Level 1+ }\end{array}$ & 49 \\
\hline 39 & $\begin{array}{l}\text { Patients with OCD who respond to antidepressants in the acute phase should be } \\
\text { continued on their medication for at least } 12 \text { months. }\end{array}$ & $\begin{array}{l}\text { Grade A, } \\
\text { Level } 1+\end{array}$ & 49 \\
\hline
\end{tabular}

\section{Management of Post-Traumatic Stress Disorder (PTSD)}

\begin{tabular}{|c|c|c|c|}
\hline No. & Recommendation & $\begin{array}{l}\text { Grade, } \\
\text { Level of evidence }\end{array}$ & $\begin{array}{l}\text { CPG } \\
\text { page no. }\end{array}$ \\
\hline 40 & $\begin{array}{l}\text { Either the SSRIs or venlafaxine may be used as first-line pharmacological treatment for } \\
\text { PTSD. }\end{array}$ & $\begin{array}{l}\text { Grade A, } \\
\text { Level } 1++\end{array}$ & 51 \\
\hline 41 & Mirtazapine may be considered as a second-line treatment for PTSD. & $\begin{array}{l}\text { Grade B, } \\
\text { Level 1+ }\end{array}$ & 51 \\
\hline 42 & $\begin{array}{l}\text { Either amitriptyline or imipramine may be considered for PTSD if the first-line and } \\
\text { second-line treatments are ineffective or poorly tolerated. }\end{array}$ & $\begin{array}{l}\text { Grade A, } \\
\text { Level } 1+\end{array}$ & 52 \\
\hline 43 & Benzodiazepines should not be used for the treatment of PTSD. & $\begin{array}{l}\text { Grade A, } \\
\text { Level 1+ }\end{array}$ & 52 \\
\hline 44 & $\begin{array}{l}\text { Risperidone, olanzapine, quetiapine, and lamotrigine may be prescribed as adjunctive } \\
\text { treatments for PTSD in conjunction with the SSRIs. }\end{array}$ & $\begin{array}{l}\text { Grade B, } \\
\text { Level 1+ }\end{array}$ & 52 \\
\hline 45 & Pharmacological treatment for PTSD should be continued for at least 12 months. & $\begin{array}{l}\text { Grade D, } \\
\text { Level } 4\end{array}$ & 53 \\
\hline
\end{tabular}




\begin{tabular}{|c|c|c|c|}
\hline No. & Recommendation & $\begin{array}{l}\text { Grade, } \\
\text { Level of evidence }\end{array}$ & $\begin{array}{l}\text { CPG } \\
\text { page no. }\end{array}$ \\
\hline 46 & CBT should be used as the first-line psychological treatment for PTSD. & $\begin{array}{l}\text { Grade A, } \\
\text { Level } 1+\end{array}$ & 53 \\
\hline 47 & $\begin{array}{l}\text { Eye Movement Desensitisation and Reprocessing therapy may be used as second-line } \\
\text { treatment for PTSD. }\end{array}$ & $\begin{array}{l}\text { Grade B, } \\
\text { Level 2++ }\end{array}$ & 54 \\
\hline 48 & $\begin{array}{l}\text { If CBT or eye movement desensitisation and reprocessing therapy for PTSD are } \\
\text { contraindicated or have failed, combination therapy (i.e. CBT plus pharmacotherapy) } \\
\text { may be used as an alternative treatment. }\end{array}$ & $\begin{array}{l}\text { Grade B, } \\
\text { Level 1+ }\end{array}$ & 54 \\
\hline
\end{tabular}

\section{Management of anxiety disorders in pregnancy}

\begin{tabular}{|c|c|c|c|}
\hline No. & Recommendation & $\begin{array}{l}\text { Grade, } \\
\text { Level of evidence }\end{array}$ & $\begin{array}{l}\text { CPG } \\
\text { page no. }\end{array}$ \\
\hline 49 & $\begin{array}{l}\text { If a woman is planning a pregnancy or becomes pregnant while on medication for an } \\
\text { anxiety disorder, consider: } \\
\text { - Stopping medication and starting CBT, if necessary and if not already tried. } \\
\text { - Switching to a safer drug, if the decision is to maintain her on medication. }\end{array}$ & $\begin{array}{l}\text { Grade D, } \\
\text { Level } 4\end{array}$ & 55 \\
\hline 50 & $\begin{array}{l}\text { When prescribing a drug for a woman with an anxiety disorder who is planning a } \\
\text { pregnancy, already pregnant, or breastfeeding: } \\
\text { - Choose drugs with the lowest risk potential for the mother and foetus/infant } \\
\text { - Start at the lowest effective dose, and slowly titrate upwards } \\
\text { - Continue for the shortest possible duration } \\
\text { - Use monotherapy instead of combination treatment }\end{array}$ & $\begin{array}{l}\text { Grade D, } \\
\text { Level } 4\end{array}$ & 56 \\
\hline 51 & Sertraline, paroxetine and citalopram should be avoided during pregnancy. & $\begin{array}{l}\text { Grade C, } \\
\text { Level 2+ }\end{array}$ & 57 \\
\hline 52 & $\begin{array}{l}\text { Benzodiazepines should not be routinely prescribed for pregnant and breastfeeding } \\
\text { women, except for the short-term treatment of extreme anxiety and agitation. }\end{array}$ & $\begin{array}{l}\text { Grade D, } \\
\text { Level } 4\end{array}$ & 59 \\
\hline 53 & $\begin{array}{l}\text { The risk-benefit ratio of prescribing benzodiazepines should be assessed on a } \\
\text { case-by-case basis; use the lowest dose for the shortest time, or avoid prescribing at all } \\
\text { during the first trimester. }\end{array}$ & GPP & 59 \\
\hline 54 & $\begin{array}{l}\text { Atypical antipsychotics should be prescribed with caution in patients suffering from or } \\
\text { at risk of gestational diabetes. }\end{array}$ & $\begin{array}{l}\text { Grade D, } \\
\text { Level } 3\end{array}$ & 59 \\
\hline 55 & $\begin{array}{l}\text { Medication for nursing mothers should be maintained at the lowest effective dose to } \\
\text { minimise infant exposure. }\end{array}$ & $\begin{array}{l}\text { Grade D, } \\
\text { Level } 3\end{array}$ & 60 \\
\hline 56 & $\begin{array}{l}\text { When antidepressant treatment is indicated in the postpartum period, women should } \\
\text { generally not be advised to discontinue breastfeeding. }\end{array}$ & $\begin{array}{l}\text { Grade D, } \\
\text { Level } 3\end{array}$ & 60 \\
\hline 57 & $\begin{array}{l}\text { Treatment with paroxetine or sertraline should be preferred over other SSRIs in } \\
\text { treatment-naive breastfeeding women due to the low infant exposure to these drugs }\end{array}$ & $\begin{array}{l}\text { Grade D, } \\
\text { Level } 3\end{array}$ & 61 \\
\hline 58 & $\begin{array}{l}\text { Drugs for which little data exist, such as fluvoxamine, venlafaxine, bupropion and } \\
\text { mirtazapine, should not be considered as first-line therapies in breastfeeding women, } \\
\text { but they may be used in special cases. }\end{array}$ & $\begin{array}{l}\text { Grade D, } \\
\text { Level } 4\end{array}$ & 61 \\
\hline 59 & $\begin{array}{l}\text { If mothers have been successfully treated with a particular SSRI, TCA or SNRI, this } \\
\text { drug should be the first-line treatment if there are no contraindications. An individual } \\
\text { risk-benefit assessment should always be done before starting antidepressants. }\end{array}$ & $\begin{array}{l}\text { Grade D, } \\
\text { Level } 4\end{array}$ & 61 \\
\hline 60 & $\begin{array}{l}\text { Women on long term treatment with high dose benzodiazepines should continue to } \\
\text { breastfeed, as stopping of benzodiazepine may precipitate withdrawal symptoms in the } \\
\text { infant. Gradual tapering and stopping of benzodiazepines may be attempted at a later } \\
\text { stage when the infant has grown bigger. }\end{array}$ & GPP & 62 \\
\hline 61 & $\begin{array}{l}\text { During maternal treatment with benzodiazepines, infants should be monitored for signs } \\
\text { of sedation, lethargy, poor feeding and weight loss. }\end{array}$ & $\begin{array}{l}\text { Grade D, } \\
\text { Level } 4\end{array}$ & 62 \\
\hline
\end{tabular}




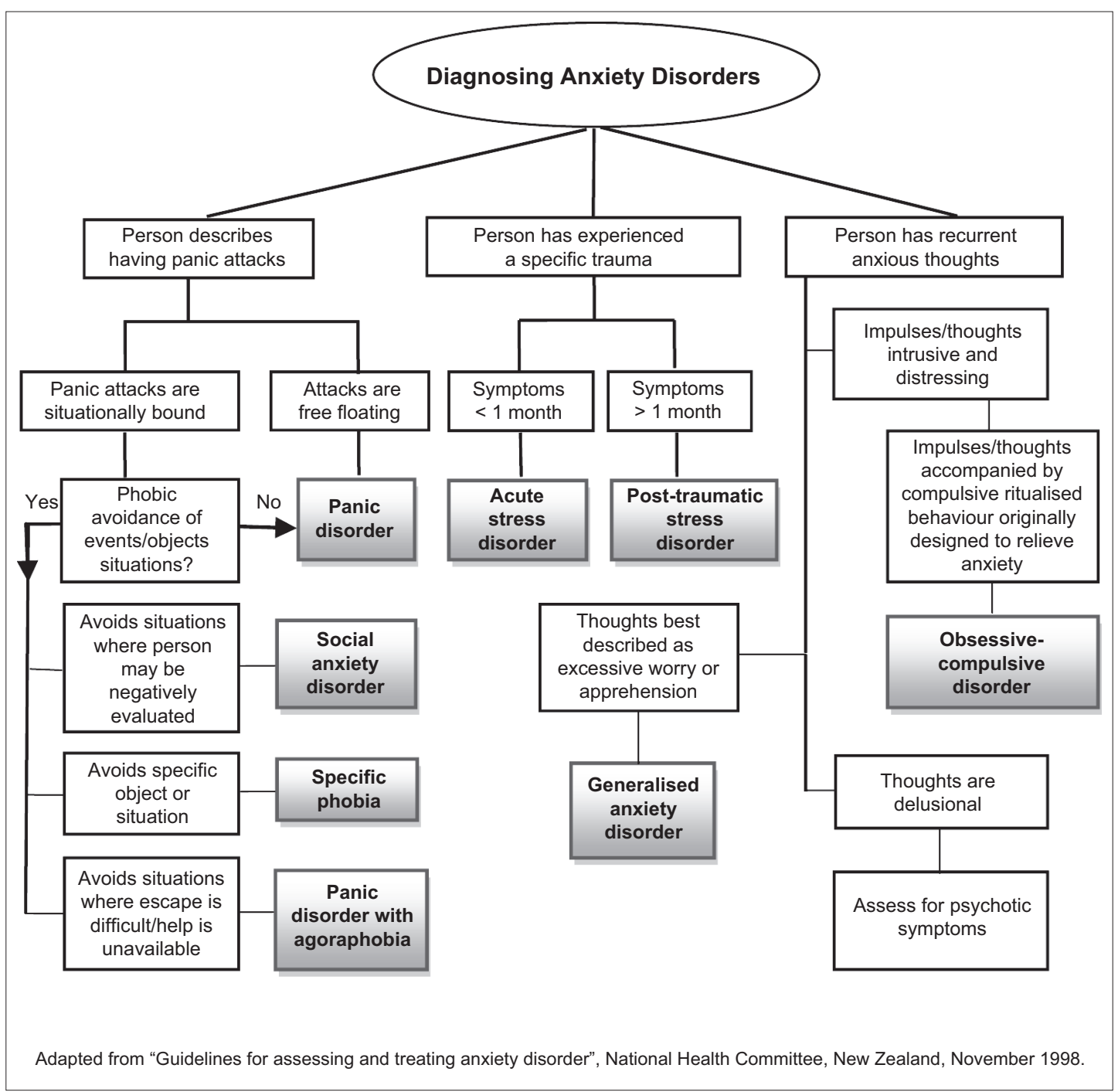

Fig. 1 Differentiating anxiety disorders.

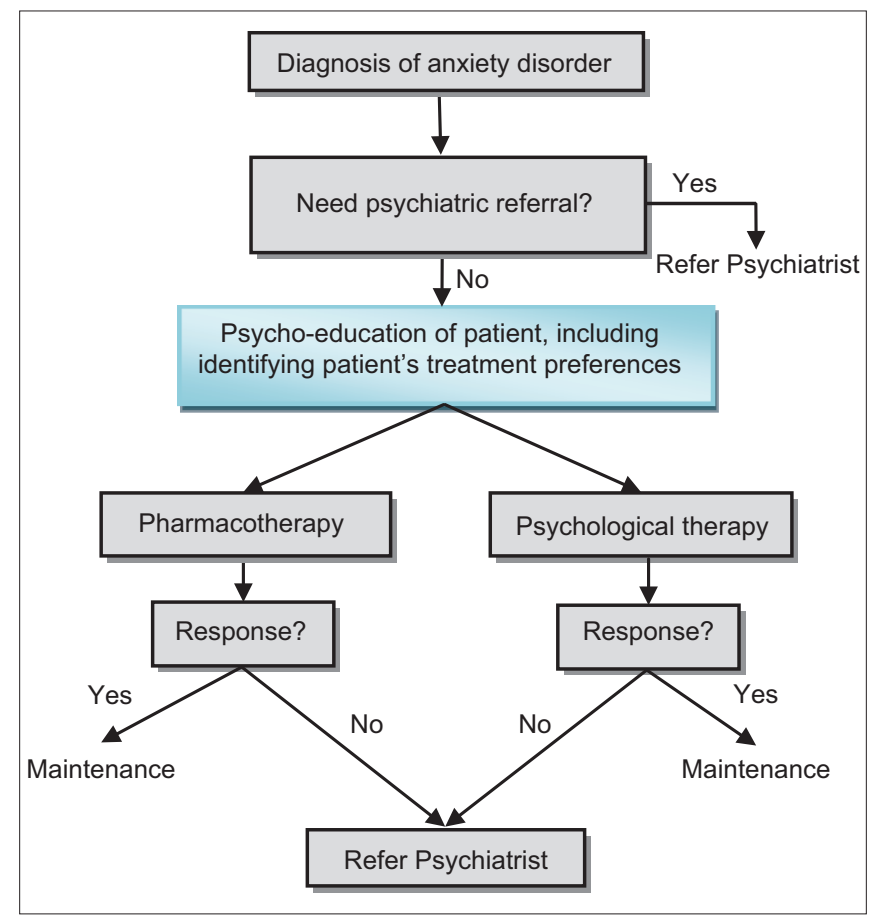

Fig. 2 Anxiety disorders management algorithm. 


\section{SINGAPORE MEDICAL COUNCIL CATEGORY 3B CME PROGRAMME} (Code SMJ 201506B)

These questions are based on the full text of the guidelines which may be found at http://www.moh.gov.sg/content/moh_web/ healthprofessionalsportal/doctors/guidelines/cpg_medical.html

Question 1. After diagnosis of an anxiety disorder in the outpatient setting, the following immediate steps

True

False should be instituted at the primary care level:

(a) Reassurances and psycho-education about the nature and origin of anxiety.

(b) Lifestyle changes, such as regular exercise.

(c) Treat psychotic symptoms if present.

(d) Refer to a psychiatrist.

Question 2. Psychiatric referral is appropriate when:

(a) Risk of suicide is serious.

(b) Anxiety disorder is first diagnosed.

(c) Pharmacological treatment for anxiety disorder is needed.

(d) Anxiety symptoms have stabilised.

Question 3. For panic disorder:

(a) Treatment response can be quantified and documented with the Panic Disorder Severity Scale (PDSS).

(b) About two-thirds of patients with panic disorder suffer from agoraphobia.

(c) Combination therapy is as efficacious as monotherapy.

(d) Cognitive behaviour therapy is not useful.

Question 4. For post-traumatic stress disorder:

(a) Alprazolam and clonazepam have been found to be superior to placebo.

(b) Amitriptyline may be considered as first-line treatment.

(c) Risperidone and lamotrigine may be prescribed as adjunctive treatments.

(d) Combination therapy is superior to trauma-focused cognitive behaviour therapy.

Question 5. Evaluate the following statements:

(a) Beta-blockers have been shown to be often useful in the treatment of social phobia.

(b) Moclobemide should be used as first line treatment for social anxiety disorder.

(c) Phobic symptoms respond best to exposure therapy to the feared situation or object.

(d) Cognitive behaviour therapy components such as systematic desensitisation, imaginal exposure and in-vivo exposure are useful in the treatment of specific phobia. $\begin{array}{ll}\square & \square \\ \square & \square \\ \square & \square \\ \square & \square\end{array}$

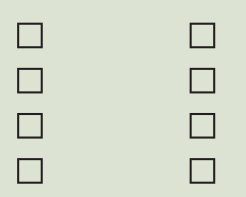

\section{Doctor's particulars:}

Name in full

MCR number

Email address

\section{SUBMISSION INSTRUCTIONS:}

(1) Log on at the SMJ website: http://www.sma.org.sg/publications/smjcurrentissue.aspx and select the appropriate set of questions. (2) Provide your name, email address and MCR number. (3) Select your answers and click "Submit".

\section{RESULTS:}

(1) Answers will be published in the SMJ August 2015 issue. (2) The MCR numbers of successful candidates will be posted online at the SMJ website by 31 July 2015. (3) Passing mark is $60 \%$. No mark will be deducted for incorrect answers. (4) The SMJ editorial office will submit the list of successful candidates to the Singapore Medical Council. (5) One CME point is awarded for successful candidates.

Deadline for submission: (June 2015 SMJ 3B CME programme): 12 noon, 24 July 2015. 